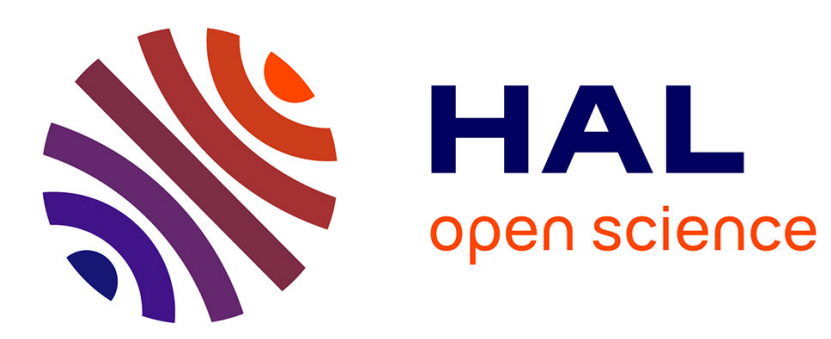

\title{
Combustion particulate emissions in Africa: regional climate modeling and validation
}

\author{
A. Konare, C. Liousse, B. Guillaume, F. Solmon, P. Assamoi, R. Rosset, J. M. \\ Gregoire, F. Giorgi
}

\section{- To cite this version:}

A. Konare, C. Liousse, B. Guillaume, F. Solmon, P. Assamoi, et al.. Combustion particulate emissions in Africa: regional climate modeling and validation. Atmospheric Chemistry and Physics Discussions, 2008, 8 (2), pp.6653-6681. hal-00328319

\section{HAL Id: hal-00328319 \\ https://hal.science/hal-00328319}

Submitted on 10 Oct 2008

HAL is a multi-disciplinary open access archive for the deposit and dissemination of scientific research documents, whether they are published or not. The documents may come from teaching and research institutions in France or abroad, or from public or private research centers.
L'archive ouverte pluridisciplinaire HAL, est destinée au dépôt et à la diffusion de documents scientifiques de niveau recherche, publiés ou non, émanant des établissements d'enseignement et de recherche français ou étrangers, des laboratoires publics ou privés. 


\section{Combustion particulate emissions in Africa: regional climate modeling and validation}

A. Konare ${ }^{1}$, C. Liousse ${ }^{2}$, B. Guillaume ${ }^{2}$, F. Solmon ${ }^{2}$, P. Assamoi ${ }^{1}$, R. Rosset ${ }^{2}$, J. M. Gregoire ${ }^{3}$, and F. Giorgi ${ }^{4}$

${ }^{1}$ Laboratoire de Physique de l'Atmosphère, Université de Cocody, Abidjan, Côte d'Ivoire

${ }^{2}$ Laboratoire d'Aérologie, Toulouse, France

${ }^{3} \mathrm{JRC}$, IES-GEM, Ispra, Italy

${ }^{4}$ International Centre for Theoretical Physics, Italy

Received: 14 December 2007 - Accepted: 13 February 2008 - Published: 7 April 2008

Correspondence to: A. Konare (konarea@yahoo.com)

Published by Copernicus Publications on behalf of the European Geosciences Union.

\section{Regional climate modeling of combustion aerosol in Africa \\ A. Konare et al.}

Title Page

Abstract

Conclusions

Tables

14

4

Back
Introduction

References

Figures

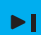

Close

Full Screen / Esc

Printer-friendly Version

Interactive Discussion 


\section{Abstract}

Africa, as a major aerosol source in the world, plays a key role in regional and global geochemical cycles and climate change. Combustion carbonaceous particles, central in this context through their radiative and hygroscopic properties, require ad hoc

5 emission inventories. These inventories must incorporate fossil fuels FF (industries, traffic,...), biofuels BF (charcoal, wood burning,... quite common in Africa for domestic use), and biomass burning BB regularly occurring over vast areas all over the African continent. This latter, subject to rapid massive demographic, migratory, industrial and socio-economic changes, requires continuous emission inventories updating, so as to keep pace with this evolution. Two such different inventories, L96 and L06 with main focus on BB emissions, have been implemented for comparison within the regional climate model RegCM3 endowed with a specialized carbonaceous aerosol module. Resulting modeled black carbon $\mathrm{BC}$ and organic carbon $\mathrm{OC}$ fields have been compared to past and present composite data set available in Africa. This data set includes mea-

15 surements from intensive field campaigns (EXPRESSO 1996, SAFARI 2000), from the IDAF/DEBITS surface network and from MODIS, focused on selected west, central and southern African sub-domains. This composite approach has been adopted to take advantage of possible combinations between satellite high-resolution coverage of Africa, regional modeling, use of an established surface network, together with the patchy detailed knowledge issued from past short intensive regional field experiments. Stemming from these particular comparisons, one prominent conclusion is the need for continuous detailed time and spatial updating of combustion emission inventories apt to reflect the rapid transformations of the African continent.

\section{Introduction}

25 Africa is a major aerosol source in the world, mainly desert dusts and combustion particles, with ensuing strong environmental direct and indirect impacts on regional/global

\section{Regional climate modeling of \\ combustion aerosol in Africa}

A. Konare et al.

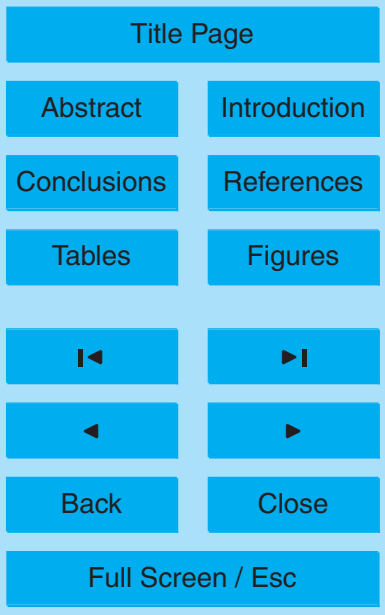

Printer-friendly Version

Interactive Discussion 
chemistry and climate. Primary carbonaceous emissions comprise BC and primary organic carbon (OCp) particles with quite distinctive radiative and hygroscopic properties.

The main combustion sources are fossil fuels FF, biofuels BF and biomass burn5 ing BB. Due to explosive demography, rural depopulation and concentration of most activities in expanding megapoles (e.g. Lagos, Johannesburg, Cairo,...), together with the development of oil, coal and other mining and industrial activities, FF emissions are rapidly growing, in spite of recent pollution abatement legislations (e.g. lead regulations in AFRICACLEAN). BF emissions are due to common domestic practice, only slightly 10 seasonally modulated. To keep pace with these evolutions, combustion emission inventories need to be regularly updated.

In this context, our focus here is on African BB emissions, highly variable in space and time, from season to season and year to year, in response to climate variability (e.g. prolonged droughts) and environmental impacts (deforestation/desertification). The effects on BC and OCp surface concentrations and column-integrated AOT (Aerosol Optical Thickness) of monthly emissions obtained from currently averaged multi-yearly lumped data in which regional BB hot spots are erased or from real-time satellite data are expected to be different. Two main points are addressed with these BB emissions. First, two BC and OCp emission inventories are compared here, denoted L96 (Liousse et al., 1996) and L06 (this work), which correspond respectively to the lumped and real-time data distinct cases above. Secondly, distinction between fire pixels and burnt areas in satellite (ATSR, SPOT-VEGETATION, MODIS) BB data results in significantly large emission differences (Liousse et al., 2004; Michel et al., 2005). In the following, the burnt areas method only has been used for the L06 inventory.

25 These two emission inventories have been implemented within the regional climate model RegCM3 (Giorgi and Mearns, 1999; Solmon et al., 2005) in order to get modeled $\mathrm{BC}$ and $\mathrm{OC}$ concentrations and derived column AOT relevant for comparisons with surface, aircraft and satellite measurements.

RegCM3 is briefly described in Sect. 2, together with the African simulation domain

\section{Regional climate modeling of combustion aerosol in Africa}

A. Konare et al.

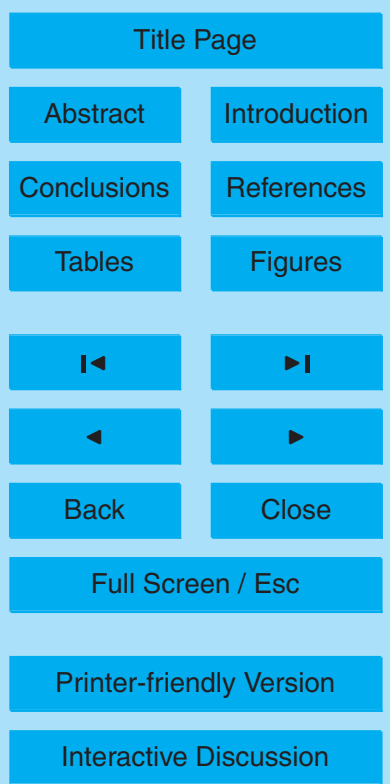

\section{5}


and its three west, central and south sub-domains subject to intense BB. Section 3 describes L96 and L06 inventories whereas Sect. 4 is devoted to comparative BC budget analyses in these sub-domains, during dry and wet seasons. In Sect. 5, RegCM3 model results are compared to available experimental data collected, respectively in

5 the IDAF (IGAC DEBITS AFRICA) surface network (west Africa) and during past field campaigns (DECAFE 1992 (Dynamique et Chimie de l'Atmosphère en Foret Equatoriale), EXPRESSO 1996 (EXperiment for REgional Sources and Sinks of Oxidants) in western and central Africa; SAFARI 2000 (South Africa Fire-Atmosphere Research Initiative) in southern Africa) and using recent MODIS satellite data covering whole Africa. 10 Conclusions and prospects are given in Sect. 6.

\section{RegCM3 description and simulation domains}

RegCM3 is the latest version of the regional climate model developed at the International Centre for Theoretical Physics (ICTP). Detailed description of this model and its parameterizations are given in a series of papers and references therein (Giorgi 15 and Mearns, 1999), with recent developments on aerosols in Qian et al. (2001) for sulfur species, Zakey et al. (2006) for desert dusts and Solmon et al. (2006) for carbonaceous aerosols. To take advantage of the fine resolution allowed by the MODIS satellite data, these evolving multi-species modeled aerosol fields are incorporated into the radiative transfer calculations (Kiehl et al., 1996), in addition to greenhouse gases, liquid and ice cloud water climatological concentrations (Kiehl and Briegleb, 1993). Since carbonaceous aerosols are into focus here, their parameterization in RegCM3 is briefly recalled. Externally mixed BC and OC particles vary between two evolving hygroscopic states, respectively hb for hydrophobics and hl for hydrophilics. Complex physico-chemical ageing of carbonaceous particles from hb to hl states are crudely parameterized using an empirical lifetime of 1.15 days (Cooke et al., 1999). At its emission, $\mathrm{BC}$ is $80 \%$ hydrophobic ( $50 \%$ for $\mathrm{OC}$ ), the rest being hydrophilic. Initial number distributions and optical properties of the four types of carbonaceous particles

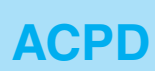

8, 6653-6681, 2008

\section{Regional climate modeling of \\ combustion aerosol in Africa}

A. Konare et al.

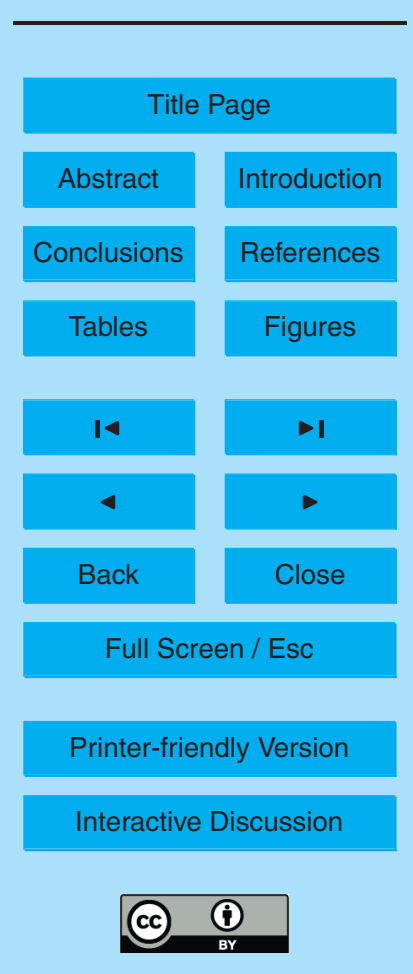


(BChb, BChl, OChb, OChl) are the same as in Table 1 of Solmon et al. (2006). During aerosol ageing, these initial ratios evolve, resulting in variable hygroscopic and radiative particle properties. Hydrophilic $B C$ and $O C$ are removed via wet deposition, not hydrophobic ones. Dry deposition velocities of hydrophilic BC and $\mathrm{OC}$ are respectively $50.2 \mathrm{~cm} / \mathrm{sec}$ over water and $0.025 \mathrm{~cm} / \mathrm{sec}$ over land, against $0.025 \mathrm{~cm} / \mathrm{sec}$ everywhere for hydrophobics.

The model domain is shown in Fig. 1, together with three sub-domains hereafter selected for budget analyses, in west, central and southern Africa. Over Africa and its oceanic margins, this domain, centered at $0^{\circ} \mathrm{N}$ and $10^{\circ} \mathrm{E}$, is covered by a horizontal 10 grid of $153 \times 153$ points at $60 \mathrm{~km}$ resolution and 18 levels in the vertical, from the surface to $5 \mathrm{hPa}$.

The NCEP (National Center for Environment and Prediction) reanalyses for the year 2000 are used to force RegCM3 at its lateral boundaries, during the simulation period from 1 December 1999 to 31 December 2000, after one-month spin-up.

\section{$3 \quad B C$ and $\mathrm{OC}$ emission inventories}

FF and BF updated emission inventories are issued from Junker and Liousse (2007). Our concern here is on BB emissions. Two distinct BB emission inventories for BC and OC, respectively denoted L96 and L06, are considered in our work. These two inventories illustrate two significantly different methodologies used for $\mathrm{BC} / \mathrm{OC}$ emissions, and subsequently their relative pertinence to capture the observed variable structure of African BB emissions from season to season. For instance, during the dry winter season of the northern hemisphere, a large latitudinal BB belt is spanning all over Africa from Ethiopia to the Atlantic, within which regional hot spots are seen which vary in intensity and location from month-to-month and year-to-year.

25 The L96 inventory commonly used in several global and regional models are based on a statistical approach (see Liousse et al., 1996) and the resulting emissions are typical of the 1990s. Briefly, a constant ratio is applied to determine the yearly burnt

\section{Regional climate modeling of \\ combustion aerosol in Africa}

A. Konare et al.

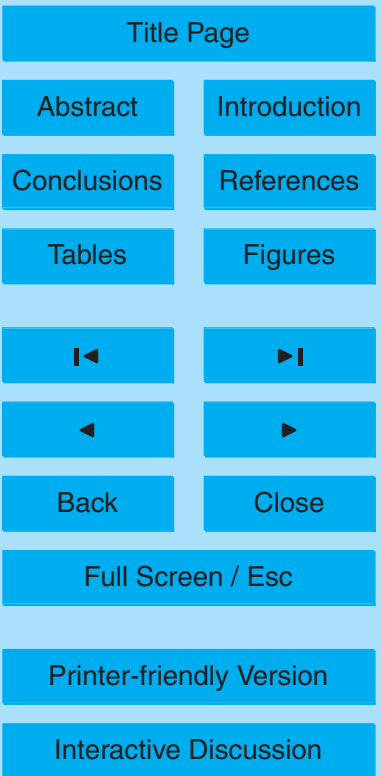

6657 
biomass estimates from vegetation areas. The L06 inventory is based on a methodology developed by Liousse et al. (2004) and Michel et al. (2005), recently applied to Africa and Asia respectively. In this method, BC and OC emissions are expressed as: $\mathrm{BC} / \mathrm{OC}$ emissions $=\mathrm{BA} \times \mathrm{FL} \times \mathrm{BE} \times \mathrm{EF}$, where $\mathrm{BA}$ are burnt areas provided by JRC Ispra 5 using GBA2000 data given by SPOT-VEGETATION satellite (Tansey et al., 2004) extrapolated to a $1^{\circ} \times 1^{\circ}$ grid at monthly resolution. FL are fuel loads issued from UMD vegetation map (University of Maryland) for the different vegetation classes and $\mathrm{BE}$ and EF, respectively the corresponding burning efficiencies and Emission factors have typical values summarized in Tables 1, 2 and 3 in Michel et al. (2005). In the absence 10 of any detailed secondary organic aerosol formation mechanism in RegCM3, this latter is grossly parameterized in L96 and L06 by multiplying OCp values by an empirical 1.25 factor (Solmon et al., 2006), so as to get total OC including OCp.

Table 1 displays annually averaged BC in L96 and L06 for the African forest and savanna fire sources (FSF sources), the other sources (agricultural and domestic (ADF), 15 biofuel and fossil (BFF) sources), being the same between L96 and L06. Values of Bond et al. (2004) have been added for comparison. On a monthly basis for the year 2000, BB BC emissions averaged over the African domain in Fig. 1 are displayed in Fig. 2, respectively for L96 (triangles) and for L06 (crosses) inventories. Clearly, there are two maxima, respectively in January, February and December in the northern and June, July, August in the southern hemispheres. Also, as expected, the L96 curve is smoother than the L06 one, due to statistical merging between disparate data, as opposed to the L06 inventory restricted to monthly values in 2000 only.

For example, the L06 December peak is associated with BB hot spots in south Sudan and République Centrafricaine (RCA) in Fig. $5 \mathrm{a}$.

\section{BC budget analyses}

Using L96 and L06 inventories, BC budget analyses obtained with RegCM3 model have been performed for December 2000 within three vertical columns extending from

\section{Regional climate modeling of combustion aerosol in Africa}

A. Konare et al.

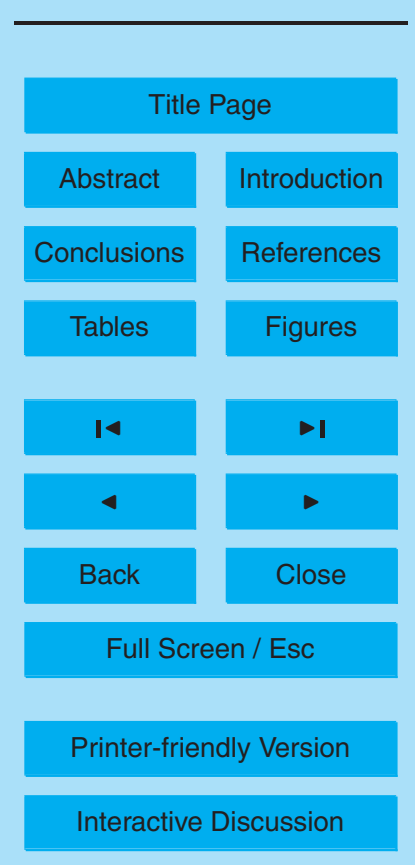


the surface to the model top at $5 \mathrm{hPa}$. These budgets include all $\mathrm{BC}$ sources (FF, BF and BB). These columns correspond to the three sub-domains in Fig. 1, with area-averaged monthly surface BC emission values. Such budget analyses (column burdens) allow to characterize import/export BC fluxes vs. regional emission and de5 position terms within specific areas, as opposed to all Africa averaged surface BC concentrations. These BC budgets are respectively shown in Fig. 3a (upper row) for west Africa, Fig. 3b (center row) for central Africa and Fig. 3c (lower row) for southern Africa, for the L96 (left column) and L06 (right column) inventories. Hydrophobic BC is in black, hydrophilic BC in grey, EM, WD and DD refer to BC emissions, wet and dry 10 deposition. As for AE, AW, AS and AN, they refer to easterly, westerly, southerly and northerly horizontal $\mathrm{BC}$ advections through the vertical faces of the three atmospheric columns. December 2000 is in the dry season in the northern hemisphere with intense BB episodes in west (Fig. 3a) and central (Fig. 3b) Africa, whereas it is the wet season in southern Africa (Fig. 3c). BC units display quite different range of values between all 15 frames.

A few salient features appear when comparing these frames in Fig. 3. First, latitudinal $B C$ fluxes (AE, AW) always predominate over meridian (AS, AN) ones. Secondly, the two north hemispheric domains (Fig. 3a and b) display during this December 2000 dry season rather similar patterns, though with different magnitudes, as opposed to South Africa (Fig. 3c). In west Africa (the two frames in the upper line in Fig. 3a), the BC budgets are similar in the L96 and L06 inventories, though with only slightly higher emission values in L06. This tends to denote the representativeness of averaged values for December 2000 in this specific area, then not subject to intense BB fires. On the contrary, for central Africa (Fig. 3b), even with seemingly-like patterns for L96 and L06, there appears about five-fold higher emissions in this latter inventory. In December 2000, this corresponds to a BB hot spot (cf. Fig. 5). As for southern Africa (Fig. 3c), $\mathrm{BC}$ budgets are quite different in L96 and L06.

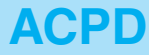

$8,6653-6681,2008$

\section{Regional climate modeling of \\ combustion aerosol in Africa}

A. Konare et al.

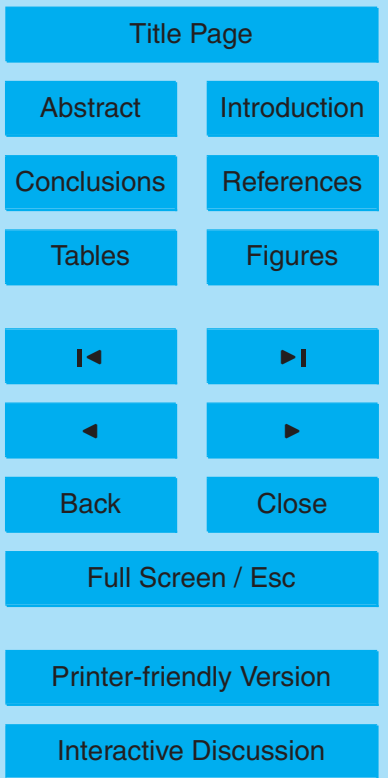


Most prominently, the L06 BC emissions are much lower than averaged ones in L96, reflecting the southern hemisphere wet season, with enhanced relative impacts of advection and wet deposition, particularly for hydrophilic BC.

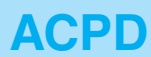

$8,6653-6681,2008$

\section{Comparisons between observations and RegCM3 simulations}

5 Due to general paucity of experimental data in Africa, these comparisons are made using an heterogeneous data set available all over Africa within the three sub-domains in Fig. 1. These comparisons are carried out in four parts, using both L96 and L06 emission inventories. In the first part, BC surface concentrations and wet deposited BC at Lamto (Ivory Coast, west Africa) are compared with the modeled results during the period 1990-1992. The second part applies to the EXPRESSO campaign which took place in winter 1996 in RCA (Central Africa). Thirdly, a comparison is made over the whole African continent between RegCM3 simulated fields and recent MODIS satellite aerosol optical depths AOT in July and December 2000. And fourthly, using L06 only, comparisons are made in southern Africa between RegCM3 outputs and SAFARI 2000 data.

\subsection{BC surface concentrations and wet deposited BC at Lamto}

In Ivory Coast, Lamto $\left(6^{\circ} 22 \mathrm{~N}, 5^{\circ} 1 \mathrm{~W}\right)$ is a wet savanna ecological reference station established since the 1960s. This west African station also continuously performs chemical measurements (gases, aerosols, wet deposition) within the IDAF network (http://medias.obs-mip.fr/idaf/). In Lamto, precipitations are maxima during the wet summer season, though never totally absent during the "dry" season. Also, though more intense and wide-spread in the dry season, domestic fires are ubiquitous in all seasons.

In Fig. 4, measured monthly surface BC concentrations (Fig. 4a) and wet deposited

\section{Regional climate modeling of \\ combustion aerosol in Africa}

A. Konare et al.

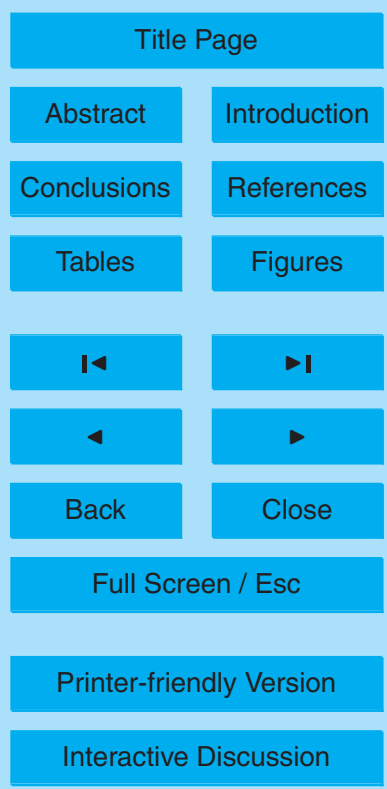


the corresponding RegCM3 simulated values, using both L96 and L06 BC emission inventories. In Fig. 4a, BC concentrations are always weaker in summer than in winter, with L96 better performing than L06 against observations, since more relevant for this period. Such clear-cut seasonal differences reflect fire predominance in winter and

5 heavier rain scavenging in summer. In Fig. 4b, these heavier summer rains give weaker wet $\mathrm{BC}$ deposition than in winter, due to much reduced $\mathrm{BC}$ fire emissions. This is in contrast to high winter $\mathrm{BC}$ wet deposition in spite of only few light rains, since more fires result in much higher BC concentrations. In Fig. 4b, both L96 and L06 summer simulations are not very different, but significantly under the observations. Such discrepancy 10 could possibly result from the parameterization of cloud and precipitation processes in RegCM3 at a coarse $60 \mathrm{~km}$ resolution.

\subsection{BC concentrations during EXPRESSO}

The EXPRESSO campaign took place in November and December 1996 (dry season) in a central African domain (Fig. 1) extending from the southern Chad savannas $15\left(12^{\circ} \mathrm{N}\right)$ to the tropical forests north of Congo $\left(2^{\circ} \mathrm{N}\right)$. Details about EXPRESSO can be found in Delmas et al. (1999) and companion papers published in a 1999 JGR special issue. RegCM3 has been run for this period, using both L96 and L06 emission inventories, and the results compared to aircraft $\mathrm{BC}$ measurements performed within the savanna (SBL) and forest (FBL) boundary layers. These comparisons are displayed in 20 Table 2, respectively for flights 1 and 2 (flight heights in parentheses) in 21, 22, 25, 28 November and 2 December (Ruellan et al., 1999). Clearly, it appears from these comparisons that for both flights and boundary layer types, the L06 BC emission inventory is significantly better performing than L96. In fact, as illustrated in Fig. 5 for December 2000 , the structure into BB hot spots of the latitudinal biomass burning belt spanning

25 Africa shows that such spots are located within the EXPRESSO central Africa domain in Fig. 1. As indicated in Sect. 3, the L06 inventory is built so as to account for such heterogeneities in BC emissions, as opposed to L96, averaged over several years in the 1990s and which display in Fig. 5, more diffuse and less intense BC emissions.

\section{Regional climate modeling of \\ combustion aerosol in Africa}

A. Konare et al.

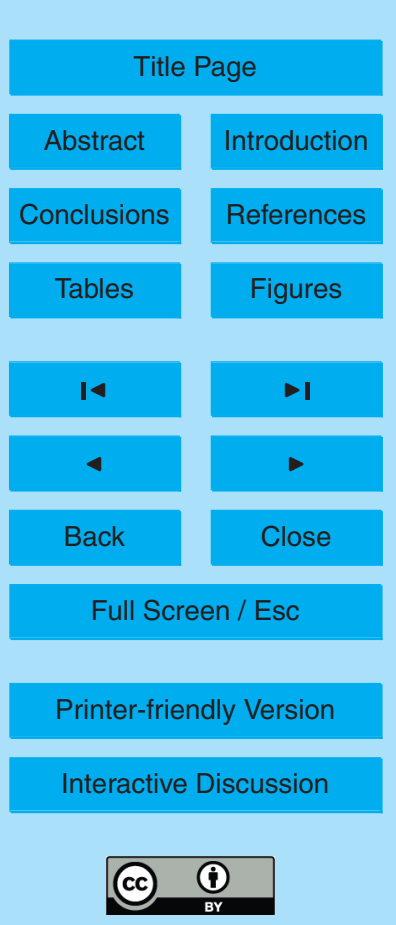


Before carrying out these comparisons between modeled RegCM3 AOTs and MODIS retrieved ones, modeled BC surface concentrations using L96 and L06 inventories are compared all over Africa.

5 5.3.1 Modeling African BC surface concentrations

Figure 5 displays modeled surface BC concentrations, respectively for December 2000 (Fig. 5a and b) and July 2000 (Fig. 5c and d), using L96 (Fig. 5a and c) and L06 (Fig. 5b and d) emission inventories. Obviously, color ranges are quite different between all frames in Fig. 5, with systematically higher values in L06 than in L96, by factors about 1010 in December and 7 in July. Such differences are due to emission averaging and smoothing over several years in the L96 inventory, whereas L06 specifically applies to December and July 2000. Within the latitudinal BB belt in December, absolute maxima BC concentrations in L06 (Fig. 5b) are located east of Nigeria, in RCA and south Sudan, with only relative maxima in west Africa, as opposed to L96 (Fig. 5a). In July 2000, 15 maxima values in the southern hemisphere appear in L06 (Fig. 5d) in Congo and north Angola, with again, resulting L96 BC fields much more diffuse and less spotty than L06 ones. In all frames in Fig. 5, the urban/industrial Gauteng/Johannesburg region in South Africa clearly appears, together with less intense emission peaks in the Durban and Cape Town areas.

\subsubsection{RegCM3 modeled vs. MODIS retrieved aerosol optical depths}

In Fig. 6, comparisons are made between RegCM3 modeled vs. MODIS (http://modis. gsfc.nasa.gov/) retrieved AOTs at $500 \mathrm{~nm}$, respectively for December 2000 (Fig. 6a, b and c) and July 2000 (Fig. 6d, e and f). For each month, the simulations incorporate sulfates and hydrophobic / hydrophilic BC and OC. MODIS data, though restricted to 25 small particles, incorporate all particle components (including dusts and sea salt). This

\section{Regional climate modeling of \\ combustion aerosol in Africa}

A. Konare et al.

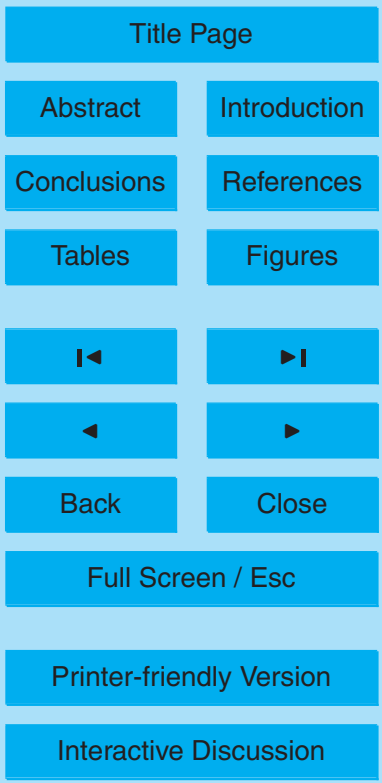


can make a significant difference between simulated and observed AOT fields, particularly in west Africa in all seasons and in July over the Red Sea. Also, in west Africa, further improvements are presumably still required in BC/OC emission inventories to better account for biofuel and domestic fires all the year round. Nevertheless, better 5 agreement is found between MODIS maps and RegCM3 simulations using L06 than L96 inventories, with less diffuse fields and more correct location and intensity of maximum AOT values. Apart from west Africa above, differences appear between L06 and MODIS fields, particularly in the extent of maximum values areas in central Africa, north and south of the equator, both in July and December 2000. Sulfate and carbonaceous 10 aerosols impacts can be found in west Nigeria and along the gulf of Guinea coasts (oil fields), also in South Africa (Gauteng mining industries).

\subsection{Focus over South Africa and SAFARI 2000}

The intensive field campaign SAFARI 2000 (Southern AFricA Regional science Initiative) took place in southern Africa from 13 August to 16 September 2000, (special issue on SAFARI-2000, 2003). Major focus was on biomass burning and aerosols.

The South African sub-domain in Fig. 1 covers the SAFARI area. Our purpose here is to compare RegCM3 simulations (using L06 inventories) with three types of measurements in SAFARI, respectively issued from flight level legs, vertical profiles and BC surface concentrations.

20 Firstly, in Table 3, reported BC concentrations with standard deviations in parentheses at seven significant locations along flight-level legs within the boundary layer (Sinha et al., 2003; Formenti et al., 2003) have been compared to RegCM3 values in the same areas. These areas respectively are in South Africa (SA), Mozambique (MOZM), Botswana (BOSTW), Zambia, Namibia, Otavi and Etosha pan (latitudes and 25 longitudes in Table 3). From this Table 3, there appears general rather good agreement between measured and modeled BC concentrations, though with some differences in Botswana and Zambia, which may be explained by emission peaks dilution within a model grid.

\section{Regional climate modeling of combustion aerosol in Africa}

A. Konare et al.

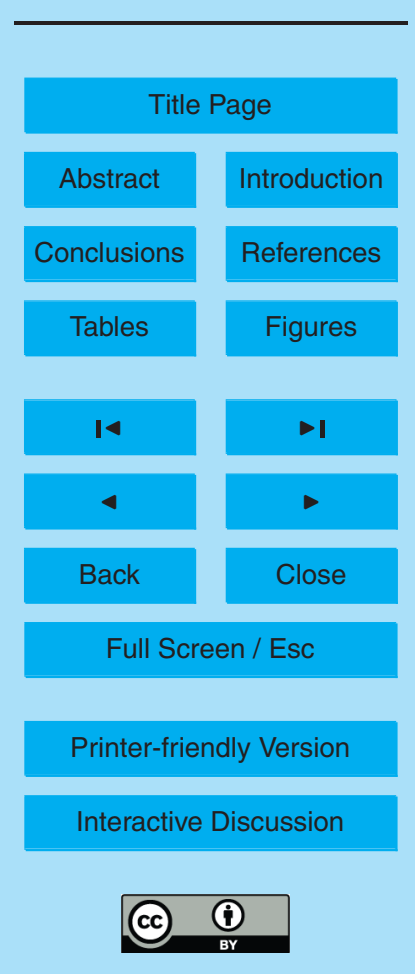


Secondly, composite aerosol vertical profiles using aircraft and lidar measurements have been published in several papers of the 2003 JGR special issue. These observed profiles (not repeated here) are compared with the RegCM3 corresponding modeled concentrations at the same locations and for the same periods. These modeled con5 centrations are displayed in figure 7 , respectively at:

- Skukuza (Fig. 7a) in South Africa, 1 September 2000 to be compared to Fig. 12 in Campbell et al. (2003);

- Mongu (Fig. 7b), 1 September 2000 (cf. Fig. 11 in Schmid et al., 2003);

- Walvis Bay (Fig. 7c) in Namibia, 11 September 2000 (cf. Fig. 12 in Schmid et al., 2003);

- Etosha Pan (Fig. 7d) in Namibia too, 13 September 2000 (cf. Fig. 12-3 in Haywood et al., 2003).

For all these cases, quite a correct agreement is found between these observed and RegCM3 simulated aerosol vertical profiles, in particular for the heights of maxima values. In fact, these heights reflect the proximity or distance of these sites from major BB areas. For instance, Mongu (Fig. 7b), located in such a burning area, displays high $\mathrm{BC}$ concentrations at low levels in the boundary layer. Skukuza (Fig. 7a), also located in a BB source region, shows a more complex vertical profile, with two peaks. The lowest one, as for Mongu, is attributable to local sources, whereas the highest one, near $700 \mathrm{hPa}$, is presumably due to remote upwind sources in Mozambique. Walvis Bay and Etosha Pan (respectively in Fig. 7c and d), away from BB sources, only display elevated $\mathrm{BC}$ peaks close to $700 \mathrm{hPa}$, due to $\mathrm{BB}$ aerosol plumes advected above these sites.

Thirdly, modeled and measured BC surface concentrations at Skukuza during SA25

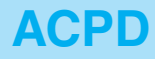

$8,6653-6681,2008$

\section{Regional climate modeling of \\ combustion aerosol in Africa}

A. Konare et al.

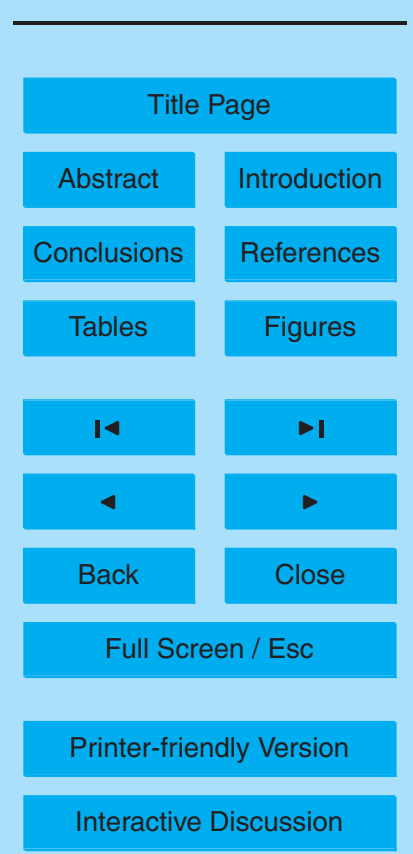


model overestimate is observed during the studied period. In spite of inherent differences (model resolution vs. point measurements, experimental procedures,...) between model results and $\mathrm{BC}$ measurements, a rather satisfactory agreement appears in Fig. 8, mainly in the timings and magnitudes of the main peaks.

\section{Conclusions and prospects}

The regional climate model RegCM3, with an implemented prognostic aerosol parameterization of hydrophobic/hydrophilic BC and OC (Solmon et al., 2006) has been run over Africa to evaluate the differential impacts of two $\mathrm{BC} / \mathrm{OC}$ emission inventories. These two inventories, L96 and L06, differ in their biomass burning sources which display natural high spatial heterogeneities together with large intra- and inter-annual variabilities. The L06 inventory closely reflects such variabilities, as opposed to the averaged L96 one. As for the composite data sets used for comparison with RegCM3 results, they are issued from two intensive field campaigns (EXPRESSO 1996 and SAFARI 2000), from the surface network IDAF and from MODIS retrieved satellite AOTs.

15 Clearly, L06 results much better capture than L96 the locations and magnitudes of observed BB sources and ensuing BC and OC concentration and AOT fields for the recent studied periods (EXPRESSO, MODIS 2000) whereas L96 better captures BC concentrations in the 1990-1992 period.

Developments, some already in progress, include updated biomass burning emissions for the whole period 2000-2007, detailed account of desert dusts, enhanced emissions in sprawling African megapoles and growing oil and mining industries, together with improved secondary organic aerosol formation. Of course, further measurements are highly required, such as in the AMMA (http://amma.mediasfrance.org/) programme.

25 Acknowledgements. This work was supported by the AMMA EU funding at Laboratoire d'Aérologie. The first author is also grateful to START PACOM research grant who offered computational facilities.

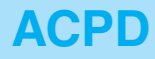

$8,6653-6681,2008$

\section{Regional climate modeling of \\ combustion aerosol in Africa}

A. Konare et al.

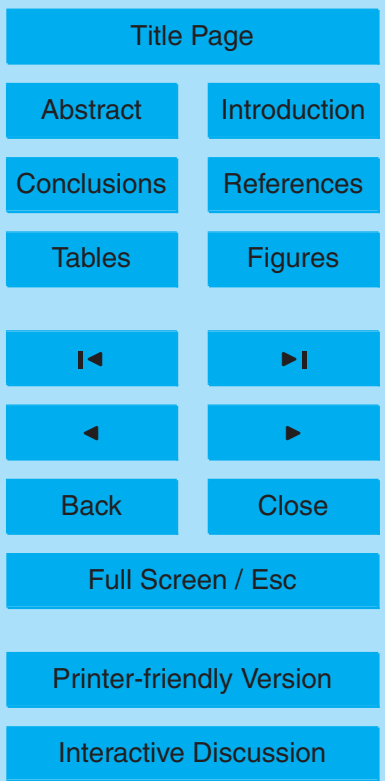




\section{References}

Bond, T. C., Streets, D. G., Yarber, K. F., Nelson, S. M., Woo, J. H., and Klimont, Z.: A technology- based global inventory of black and organic carbon emissions from combustion, J. Geophys. Res., 109, D14203, doi:10.1029/2003JD003697, 2004.

5 Campbell, J. R., Welton, E. J., Spinhirne, J. D., Ji, Q., Tsay, S. C., Piketh, S. J., Barenbrug, M., and Holben, B. N.: Micropulse lidar observations of tropospheric aerosols over northeastern South Africa during the ARREX and SAFARI 2000 dry season experiments, J. Geophys. Res., 108(D13), 33-1-33-19, 2003.

Cooke, W. F., Liousse, C., Cachier, H., and Feichter, J.: Construction of a $1^{\circ} \times 1^{\circ}$ fossil-fuel emission dataset for carbonaceous aerosol and implementation in the ECHAM model, J. Geophys. Res., 104, 22 137-22 162, 1999.

Delmas, R. A., Druilhet, A., Cros, B., Durand, P., Delon, C., Lacaux, J. P., Brustet, J. M., Serca, D., Affre, C., Guenther, A., Greenberg, J., Baugh, W., Harley, P., Klinger, L., Ginoux, P., Brasseur, G., Zimmerman, P. R., Gregoire, J. M., Janodet, E., Tournier, A., Perros, P., Marion, T., Gaudichet, A., Cachier, H., Ruellan, S., Masclet, P., Cautenet, S., Poulet, D., Bouka-Biona, C., Nganga, D., Tathy, J. P., Minga, A., Loemba-Ndembi, J., and Ceccato, P.: EXPeriment for Regional Sources and Sinks of Oxidants (EXPRESSO ): an overview, J. Geophys. Res., 104(D23), 30 609-30 624, 1999.

Formenti, P., Elbert, W., Maenhaut, W., Haywood, J., Osborn, S., and Andreae, M. O.: Inorganic and carbonaceous aerosols during the Southern AFricAn Regional science Initiative (SAFARI 2000) experiment: Chemical characteristics, physical properties, and emission data for smoke from African biomass burning, J. Geophys. Res., 108(D13), 24-1-24-14, 2003.

Giorgi, F. and Mearns, L. O.: Introduction to special session: Regional climate modeling revisited, J. Geophys. Res., 104(D6), 6335-6352, 1999.

25 Haywood, J. M., Osborn, S. R., Francis, P. N., Keil, A., Formenti, P., Andreae, M. O., and Kaye, P. H.: The mean physical and optical properties of regional haze dominated by biomass burning aerosol measured from the C-130 aircraft during SAFARI 2000, J. Geophys. Res., 108(D13), 9-1-9-14, 2003.

Junker, C. and Liousse, C.: A Global Emission Inventory of Carbonaceous Aerosol including 30 Fossil Fuel and Biofuel sources for the period 1860-1997, Atmos. Chem. Phys. Discuss., 6, 4897-4927, 2006,

http://www.atmos-chem-phys-discuss.net/6/4897/2006/.

\section{Regional climate modeling of \\ combustion aerosol in Africa}

A. Konare et al.

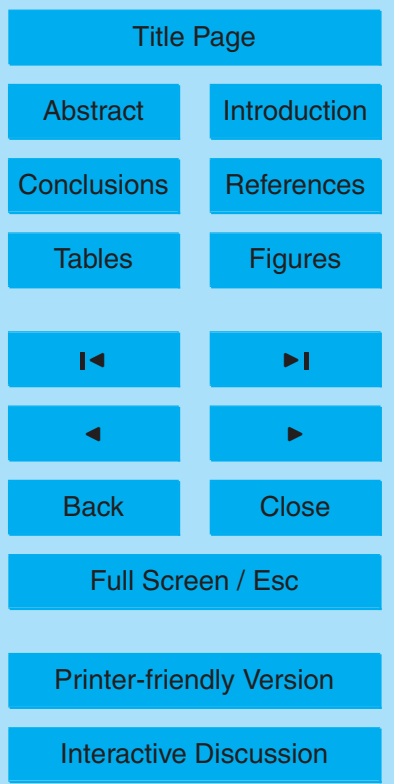


Kiehl, J. T. and Briegleb, B. P.: The relative role of sulfate aerosols and greenhouse gases in climate forcing, Science, 260, 311-314, 1993.

Kiehl, J. T., Hack, J. J., Bonan, G. B., Boville, B. A., Breigleb, B. P, Williamson, D. L., and Rasch, P. J.: Description of the NCAR Community Climate Model (CCM3), NCAR Tech.

$5 \quad$ Note, NCAR/TN-420+STR, 152 pp., Natl. Cent. for Atmos. Res., Boulder, Colorado, 1996.

Liousse, C., Penner, J. E., Chuang, C., Walton, J. J., Edelman, H., and Cachier, H.: A global three-dimensional model study of carbonaceous aerosols, J. Geophys. Res., 105, $26871-$ $26890,1996$.

Liousse, C., Andreae, M. O., Artaxo, P., Barbosa, P., Cachier, H., Gregoire, J. M., Hobbs, P., Lavoue, D., Mouillot, F., Penner, J., and Scholes, M.: Deriving global quantitative estimates for spatial and temporal distributions of biomass burning emissions, in: Emissions of atmospheric trace compounds, edited by: Granier, C., P. Artaxo and Reeves, C., Kluwer Academic Publishers, Dordrecht, The Netherlands, 544 pp., 2004.

Michel, C., Liousse, C., Grégoire, J. M., Tansey, K., Carmichael, G. R., and Woo, J. H.: Biomass burning emission inventory from burnt area data given by the SPOT-VEGETATION system in the frame of TRACE-P and ACE-ASIA campaigns, J. Geophys. Res., 110, D09304, doi:10.1029/2004JD005461, 2005.

MODIS: http://modis.gsfc.nasa.gov/

Qian, Y., Giorgi, F., Huang, Y., Chameides, W., and Luo, C.: Regional simulation of anthropogenic sulfur over East Asia and its sensitivity to model parameters, Tellus B, 53, 171-191, 2001.

Ruellan, S., Cachier, H., Gaudichet, A., Masclet, P., and Lacaux, J. P.: Airborne aerosols over Central Africa during the EXPeriment for Regional Sources and Sinks of Oxidants (EXPRESSO ), J. Geophys. Res., 104(D23), 30 673-30 690, 1999.

Swap, R. J., Annegarn, H. J., Suttles, J. T., King, M. D., Platnick, S., Privette, J. L., and R. J. Scholes: Africa burning: A thematic analysis of the Southern African Regional Science Initiative (SAFARI 2000), J. Geophys. Res., 108(D13), 8465, doi:10.1029/2003JD003747, 2003.

Schmid, B., Redeman, J., Russell, P. B., Hobbs, P. V., Hlavska, D. L., McGill, M. J., Holben, 30 B. N., Welton, E. J., Campbell, J. R., Torres, O., Kahn, R. A., Diner, D. J., Helmlinger, M. C., Chu, D. A., Robles-Gonzalez, C., and de Leeuw, G.: Coordinated airborne, spaceborne, and ground-based measurements of massive thick aerosol layers during the dry season in southern Africa, J. Geophys. Res., 108(D13), 32-1-32-23, 2003.

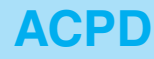

8, 6653-6681, 2008

\section{Regional climate modeling of \\ combustion aerosol in Africa}

A. Konare et al.

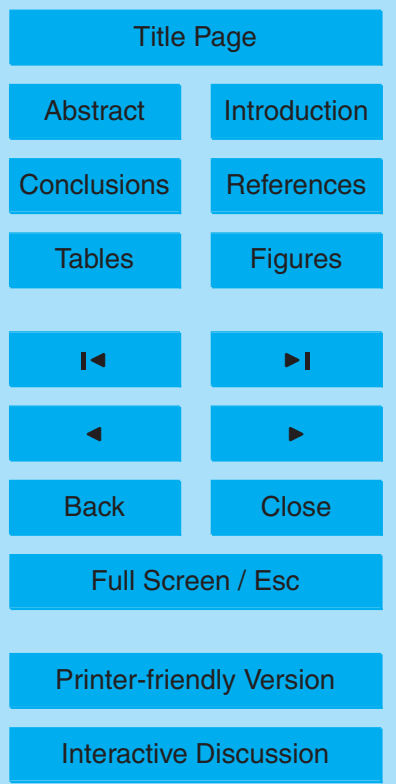


Sinha, P., Hobbs, P. V., Yokelson, R. J., Blake, D. R., Gao, S., and Kirchstetter, W.: Distributions of trace gases and aerosols during the dry biomass burning season in southern Africa, J. Geophys. Res., 108(D13), 4-1-4-23, 2003.

Solmon, F., Giorgi, F., and Liousse, C.: Aerosol modelling for regional climate studies: application to anthropogenic particles and evaluation over a European/African domain, Tellus B, 58(1), 51-72, 2006.

Tansey, K., Grégoire, J. M., Stroppiana, D., Souza, A., Silva, J. M. N., Pereira, J. M. C., Boshetti, L., Maggi, M., Brivio, P. A., Fraser, R., Flasse, S., Ershov, D., Binaghi, E., Graetz, D., and Peduzzi, P.: Vegetation burning in the year 2000: Global burned aera estimates from SPOT VEGETATION data, J. Geophys. Res.-Atmos., 109, D14S03, doi:10.1029/2003JD003598, 2004.

Zakey, A. S., Solmon, F., and Giorgi, F.: Development and testing of a desert dust module in a regional climate model, Atmos. Chem. Phys. Discuss., 6, 1749-1792, 2006,

http://www.atmos-chem-phys-discuss.net/6/1749/2006/.

\section{ACPD}

$8,6653-6681,2008$

\section{Regional climate modeling of \\ combustion aerosol in Africa}

A. Konare et al.

Title Page

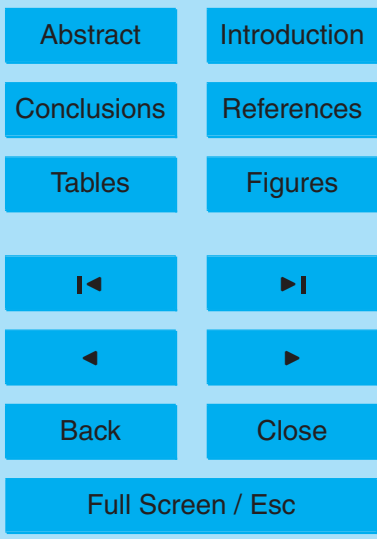

Printer-friendly Version

Interactive Discussion 


\section{ACPD}

$8,6653-6681,2008$

\section{Regional climate modeling of combustion aerosol in Africa}

A. Konare et al.

Table 1. Yearly African BC and OC emissions (in Tg) due to Forest and Savannah fires (FSF) for both L96 and L06 inventories. Bond et al., 2004 values have been added for comparison.

\begin{tabular}{llll}
\hline BC (Tg) & L96 & L06 & Bond et al., 2004 \\
\hline FSF & 1.15 & 1.66 & 1.41 \\
\hline
\end{tabular}

Title Page

Abstract Introduction

Conclusions References

14

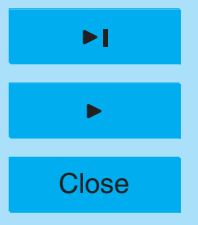

Back

Full Screen / Esc

Printer-friendly Version

Interactive Discussion 
Table 2. Comparison between $\mathrm{BC}$ (in $\mu \mathrm{gC} / \mathrm{m}^{3}$ ) modeled and averaged aircraft measurements (flights 1 and 2) during EXPRESSO 1996 for L96 and L06 emission inventories. SBL and FBL respectively refer to savannah and forest boundary layers (with corresponding flight days). Flight level heights are in parentheses.

\begin{tabular}{|c|c|c|c|}
\hline \multicolumn{2}{|c|}{ EXPRESSO } & FLIGHT 1 & FLIGHT 2 \\
\hline & & L06 L96 & L06 L96 \\
\hline SBL & MODEL & 6.21 .05 & $6.4 \quad 1.1$ \\
\hline $21 / 11$ & OBS & $8.4(540 \mathrm{~m})$ & $6.66(1090 \mathrm{~m})$ \\
\hline SBL & MODEL & $8.5 \quad 1.3$ & $\begin{array}{ll}7.90 & 1.25\end{array}$ \\
\hline $22 / 11$ & OBS & $11.82(509 \mathrm{~m})$ & $16.83(985 \mathrm{~m})$ \\
\hline FBL & MODEL & 0.72 & \\
\hline $25 / 11$ & OBS & $1.13(727 \mathrm{~m})$ & \\
\hline FBL & MODEL & 0.82 & 0.85 \\
\hline $28 / 11$ & OBS & 3.97 (548 m) & $7.3(1136 \mathrm{~m})$ \\
\hline SBL & MODEL & 1.15 & \\
\hline $02 / 12$ & OBS & $9(540 \mathrm{~m})$ & \\
\hline FBL & MODEL & 0.85 & \\
\hline $02 / 12$ & OBS & $2.62(1608 \mathrm{~m})$ & \\
\hline
\end{tabular}

\section{ACPD}

$8,6653-6681,2008$

\section{Regional climate modeling of combustion aerosol in Africa}

A. Konare et al.

Title Page

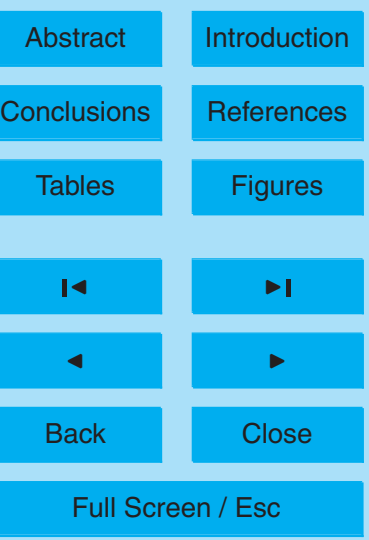

Printer-friendly Version

Interactive Discussion 


\section{ACPD}

8, 6653-6681, 2008

\section{Regional climate modeling of combustion aerosol in Africa}

A. Konare et al.

Table 3. Comparison of modeled BC (in $\mu \mathrm{gC} / \mathrm{m}^{3}$ ) vs. measured BC after * (Sinha et al., 2003) and $^{* *}$ (Formenti et al., 2003). Standard deviations are in parentheses.

\begin{tabular}{|c|c|c|c|c|c|c|c|}
\hline & $\begin{array}{l}{ }^{*} S A \\
\text { lat }=23.99 \mathrm{~S} \\
\text { lon }=29.15 \mathrm{E}\end{array}$ & $\begin{array}{l}{ }^{*} \mathrm{MOZM} \\
\text { lat }=26.10 \mathrm{~S} \\
\text { lon }=32.79 \mathrm{E}\end{array}$ & $\begin{array}{l}{ }^{*} \text { BOSTW } \\
\text { lat }=20.68 \mathrm{~S} \\
\text { lon }=26.29 \mathrm{E}\end{array}$ & $\begin{array}{l}{ }^{*} \text { ZAMBIA } \\
\text { lat }=15.98 \mathrm{~S} \\
\text { lon }=24 \mathrm{E}\end{array}$ & $\begin{array}{l}{ }^{*} \text { NAMIBIA } \\
\text { lat }=19.89 \mathrm{~S} \\
\text { lon }=14.20 \mathrm{E}\end{array}$ & $\begin{array}{l}{ }^{* *} \text { OTAVI } \\
\text { lat }=19.40 \mathrm{~S} \\
\text { lon }=17.24 \mathrm{E}\end{array}$ & $\begin{array}{l}{ }^{* *} \text { ETOSHA } \\
\text { lat }=19.20 \mathrm{~S} \\
\text { lon }=15.94 \mathrm{E}\end{array}$ \\
\hline MOL & 0.8 & 0.8 & 0.7 & 2.27 & 0.43 & 1.1 & 0.83 \\
\hline SAFARI & $1.1(0.4)$ & $1(0.5)$ & $2.6(1.4)$ & $5.5(1.4)$ & 1 & $2(1.3)$ & $1.03(0.038)$ \\
\hline
\end{tabular}

Title Page

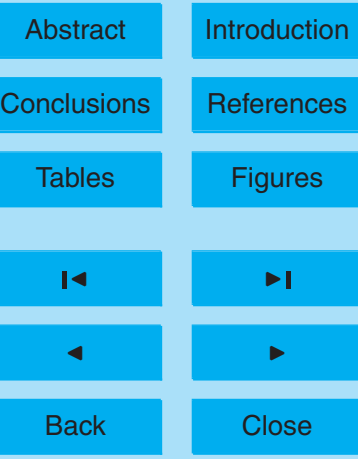

Full Screen / Esc

Printer-friendly Version

Interactive Discussion 


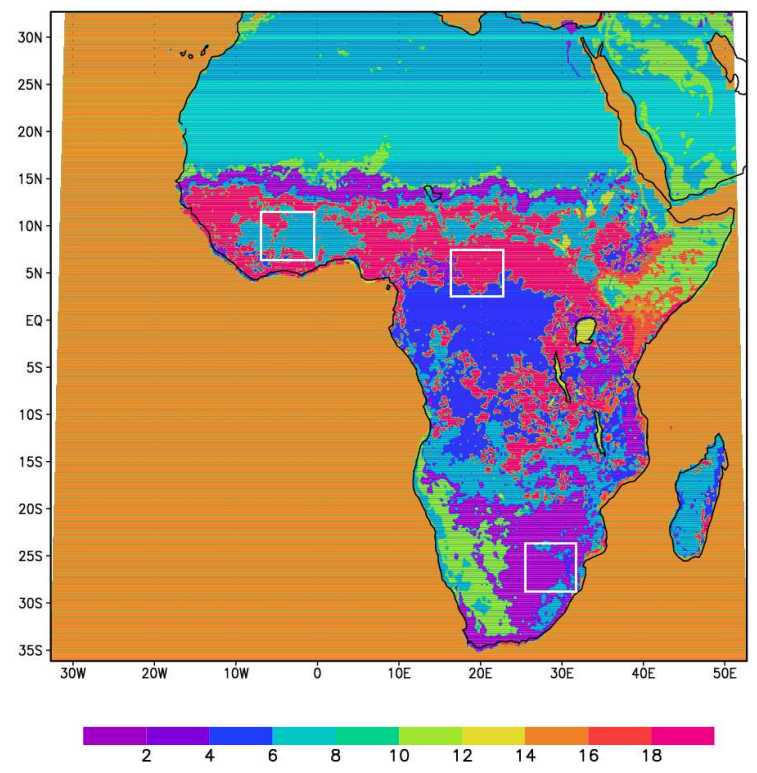

Fig. 1. The African model domain. The three west, central and southern African sub domains (boxes) are superimposed upon RegCM land cover/vegetation classification (RegCM users guide). The colour scale is used to denote the 20 Land Cover/Vegetation classes.

1. Crop/mixed farming

2. Short grass

3. Evergreen needleleaf tree

4. Deciduous needleleaf tree

5. Deciduous broadleaf tree

6. Evergreen broadleaf tree

7. Tall grass

8. Desert

9. Tundra

10. Irrigated Crop
11. Semi-desert

12. Ice cap/glacier

13. Bog or marsh

14. Inland water

15. Ocean

16. Evergreen shrub

17. Deciduous shrub

18. Mixed Woodland

19. Forest/Field mosaic

20. Water and land mixture

\section{ACPD}

8, 6653-6681, 2008

\section{Regional climate modeling of \\ combustion aerosol in Africa}

A. Konare et al.

Title Page

Abstract

Introduction

Conclusions

References

Tables

Figures

14

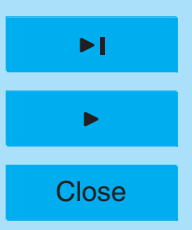

Back

Full Screen / Esc

Printer-friendly Version

Interactive Discussion 


\section{ACPD}

8, 6653-6681, 2008

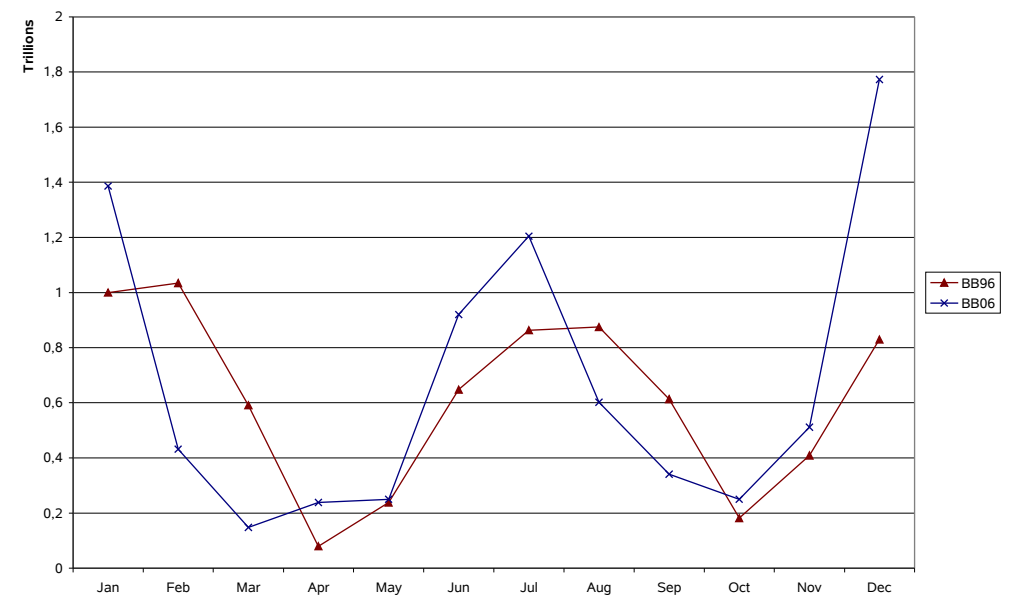

\section{Regional climate modeling of combustion aerosol in Africa}
A. Konare et al.

Title Page

Fig. 2. Monthly biomass burning $B C$ emissions ( in $\mathrm{TgC}$ ) for the year 2000. Averaging is over the African domain in Fig. 1. Triangles are for L96 inventory, crosses for L06. 
(a)
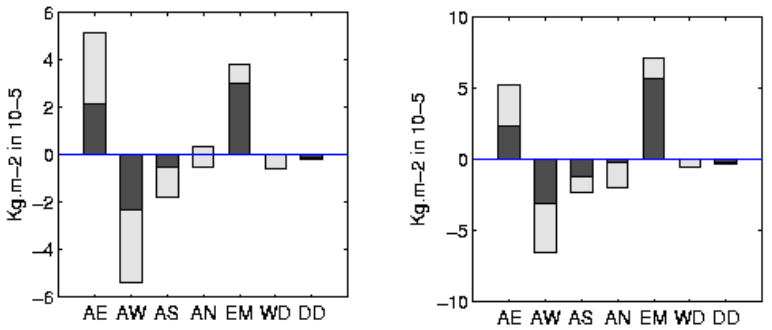

(b)
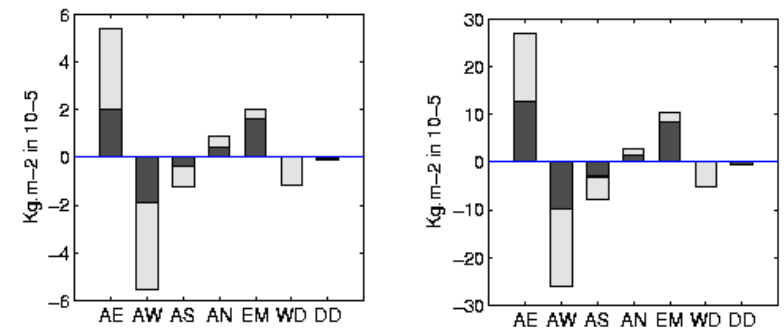

(c)
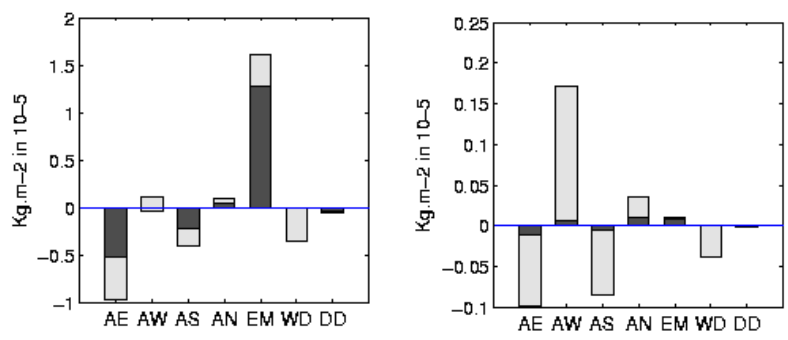

Fig. 3. $B C$ budget analyses (in $10^{-5} \mathrm{~kg} / \mathrm{m}^{2}$ ) for december 2000 in the sub-domains in Fig. 1: (a) West Africa ; (b) Central Africa ; (c) South Africa. Left frames refer to inventory L96, right ones to L06. Hydrophobic BC in black shade, hydrophilic BC in grey shade. AE, AW, AS, AN respectively refer to east, west, south and north advection, EM for $B C$ emissions, WD and DD for wet and dry deposition.

\section{ACPD}

$8,6653-6681,2008$

\section{Regional climate modeling of combustion aerosol in Africa}

A. Konare et al.

Title Page

Abstract Introduction

Conclusions

References

Tables

Figures

14

$\rightarrow$

Back

Close

\section{Full Screen / Esc}

Printer-friendly Version

Interactive Discussion 


\section{ACPD}

8, 6653-6681, 2008

(a)

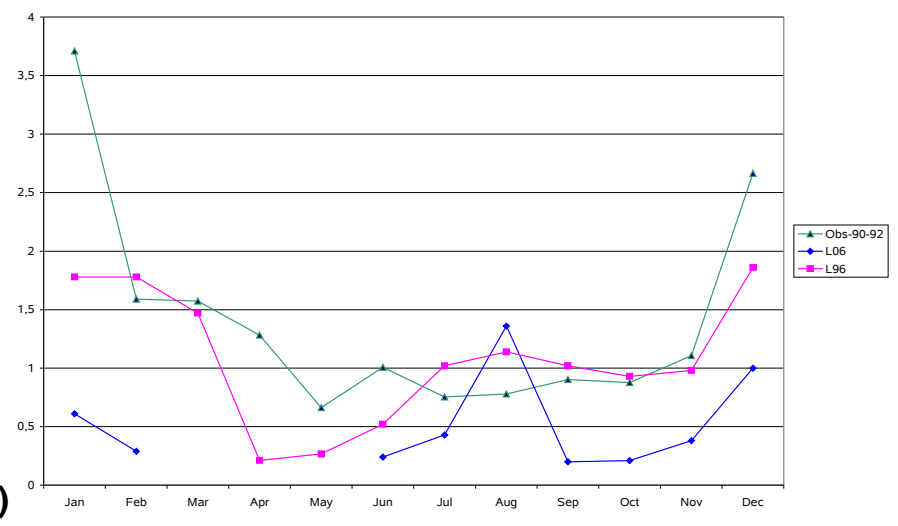

\section{Regional climate modeling of \\ combustion aerosol in Africa}

A. Konare et al.

(b)

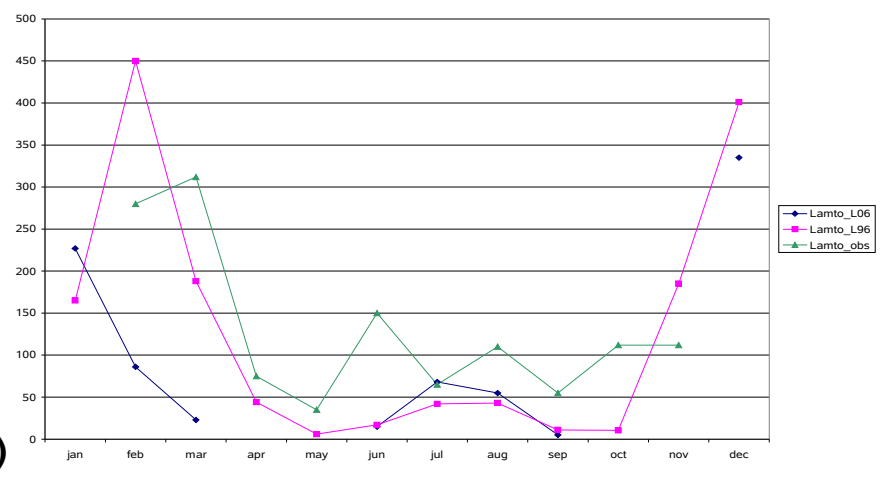

Fig. 4. Monthly $B C$ values averaged during the period $1990-1992$ at Lamto $\left(6^{\circ} 22 \mathrm{~N} ; 5^{\circ} 1 \mathrm{~W}\right)$ : (a) BC surface concentrations (in $\mu \mathrm{gC} \mathrm{m}^{-3}$ ); (b) wet deposited $\mathrm{BCg} \mu \mathrm{gl}^{-1}$. (Triangles for measurements, squares for RegCM3 simulations with L96 inventory, diamonds for RegCM3 simulations using L06 inventory).
Title Page

Abstract

Introduction

Conclusions

References

Tables

Figures

14

4

Back

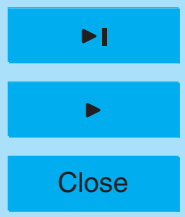

Full Screen / Esc

Printer-friendly Version

Interactive Discussion 


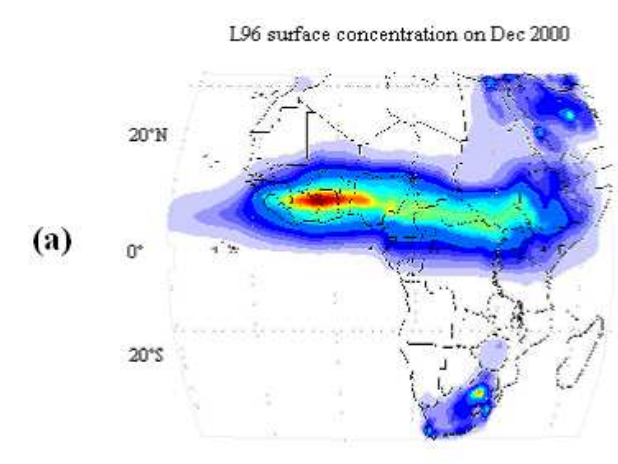

\section{ACPD}

8, 6653-6681, 2008

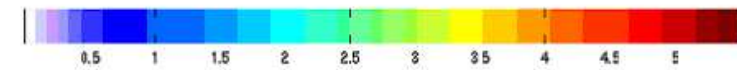

Lo6 surface concentration on Dec 2000

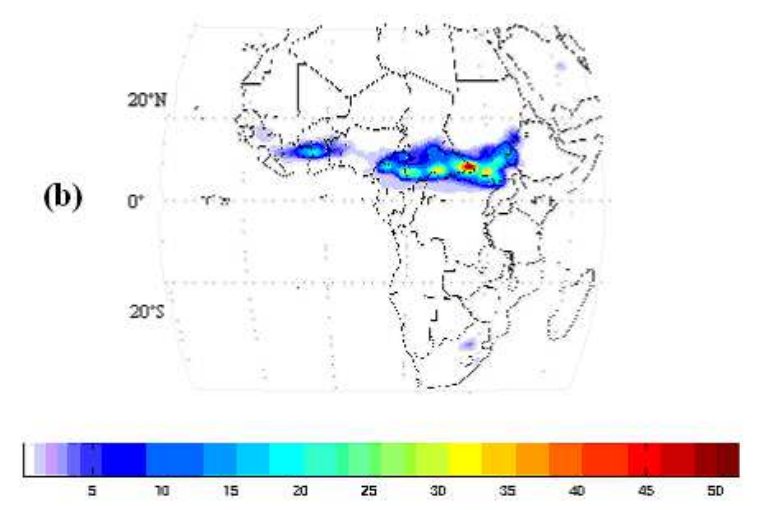

\section{Regional climate modeling of combustion aerosol in Africa}

A. Konare et al.

Title Page

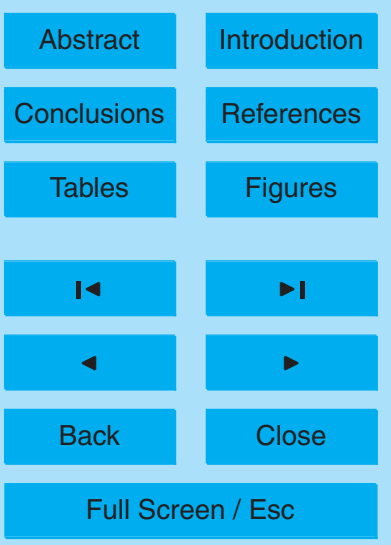

Fig. 5. $\mathrm{BC}$ surface concentrations (in $\mu \mathrm{g} \mathrm{m}^{-3}$ ), respectively for:

Printer-friendly Version

(a) L96 inventory, December 2000;

(b) L06 inventory, December 2000;

Interactive Discussion 


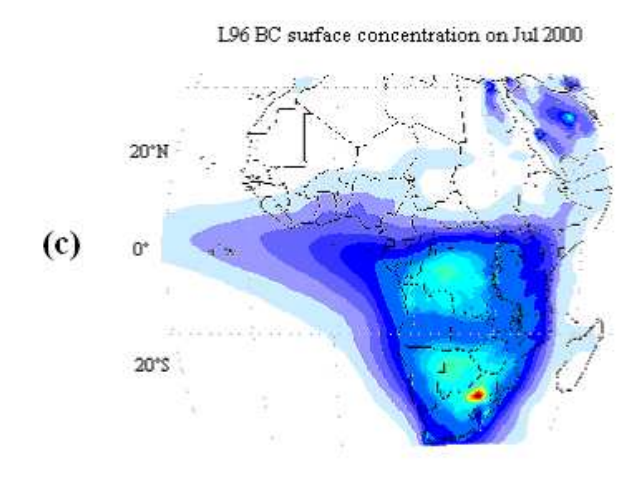

\section{ACPD}

8, 6653-6681, 2008

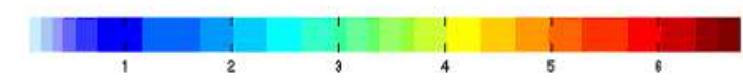

Lo6 surface concentration on Jul 2000

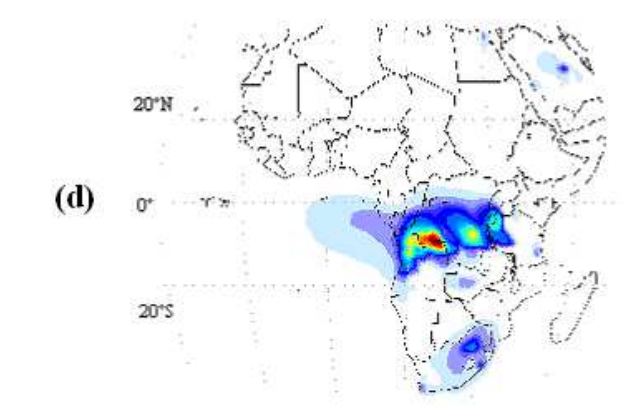

\section{Regional climate modeling of combustion aerosol in Africa}
A. Konare et al.

Title Page

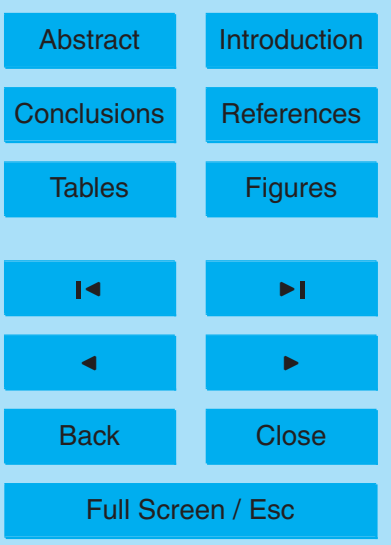

Fig. 5. Continued.

(c) L96 inventory, July 2000;

(d) L06 inventory, July 2000.

Printer-friendly Version

Interactive Discussion 
(a)
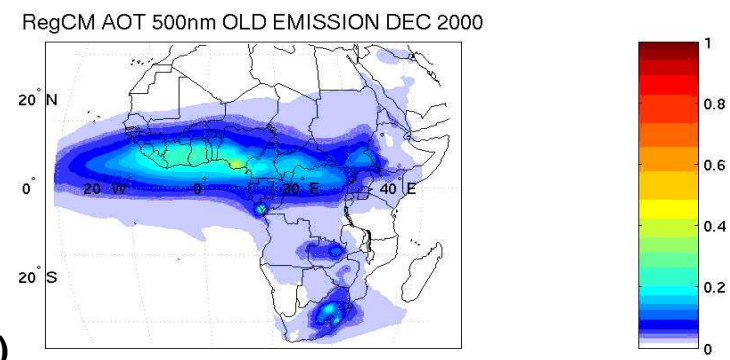

(b)
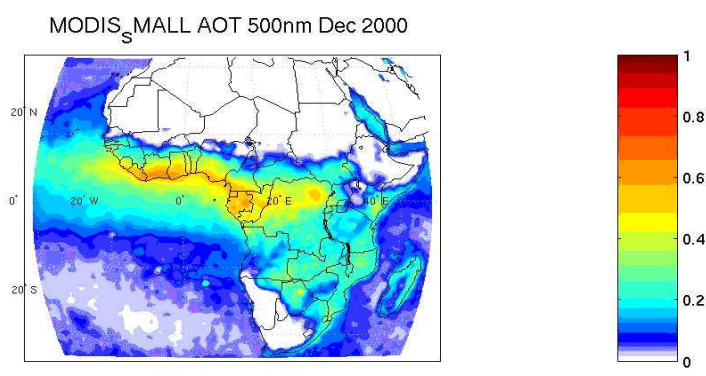

RegCM AOT 500nm NEW EMISSION Dec 2000

(c)
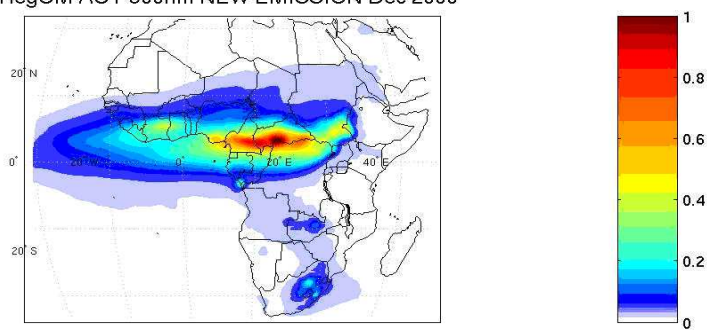

\section{ACPD}

8, 6653-6681, 2008

\section{Regional climate modeling of combustion aerosol in Africa}
A. Konare et al.

Title Page

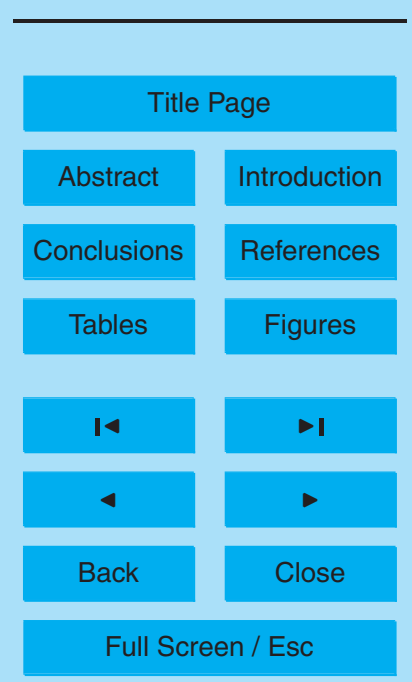

Printer-friendly Version

Interactive Discussion

(a) RegCM3 simulations, L96 inventory, December 2000;

(b) MODIS (small particles), December 2000;

(c) RegCM3 simulations, L06 inventory, December 2000; 
(d)

(e)

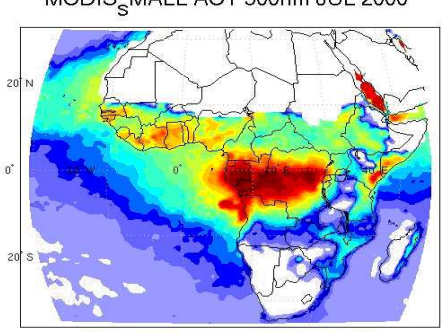

RegCM AOT 500nm NEW EMISSION JUL 2000

(f)

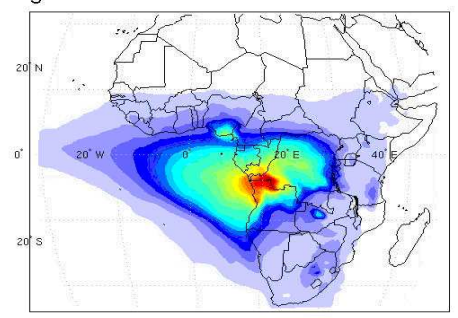

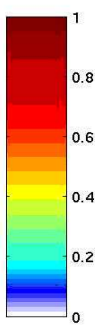
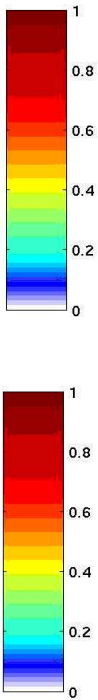

ACPD

8, 6653-6681, 2008

\section{Regional climate modeling of combustion aerosol in Africa}

A. Konare et al.

Title Page

Abstract

Introduction

Conclusions

References

Tables

Figures

14

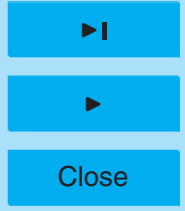

Back

Full Screen / Esc

Fig. 6. Continued.

(d) RegCM3 simulations, L96 inventory, July 2000;

Printer-friendly Version

(e) MODIS (small particles), July 2000;

(f) RegCM3 simulations, L06 inventory, July 2000.

Interactive Discussion 

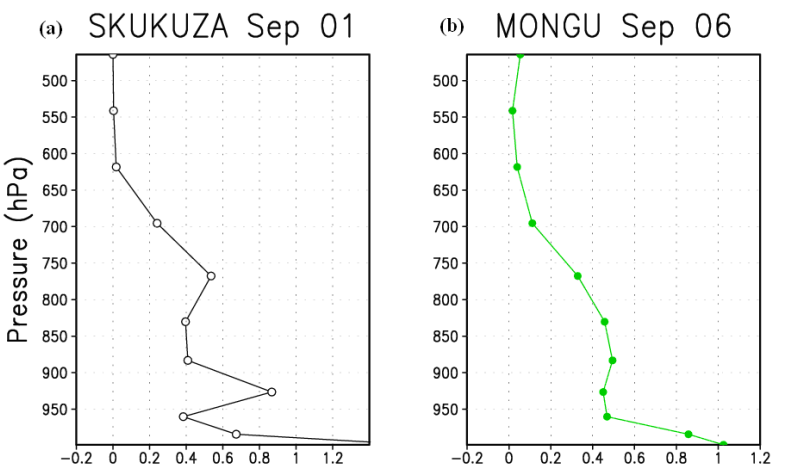

\section{ACPD}

\section{$8,6653-6681,2008$}

\section{Regional climate modeling of combustion aerosol in Africa}

A. Konare et al.

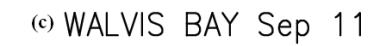

(d) ETOSHA Sep 13

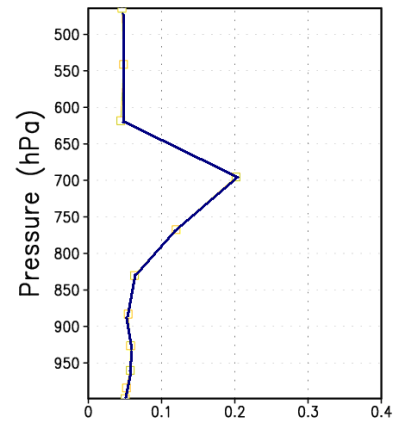

Concentration (microg/m3)

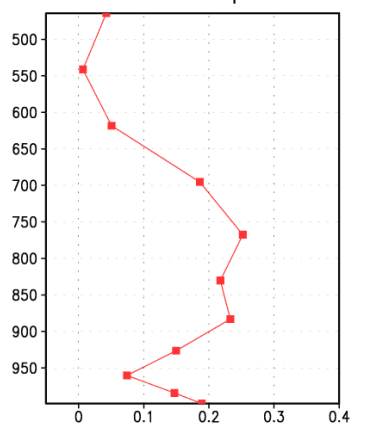

Concentration (microg/m3)

Fig. 7. Simulated BC aerosol vertical profiles at four Southern African sites (a) Skukuza; (b) Mongu; (c) Walvis Bay; (d) Etosha) within and away from BB source areas (pressure in ordinates and layer-averaged extinction coefficients in abscissa).

Title Page

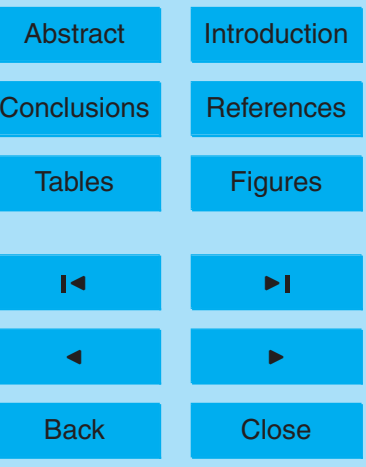

Full Screen / Esc

Printer-friendly Version

Interactive Discussion 


\section{ACPD}

$8,6653-6681,2008$

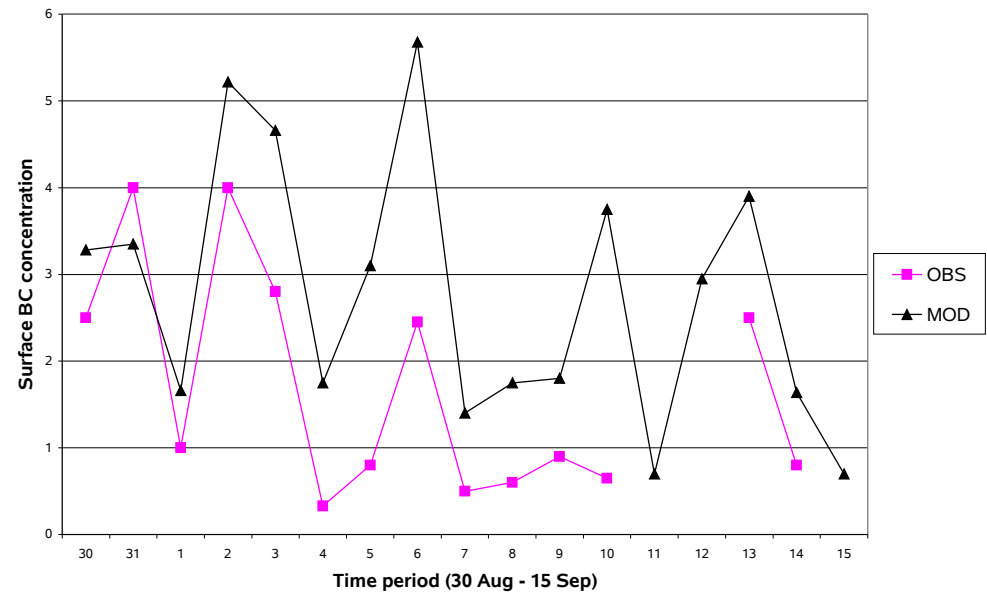

\section{Regional climate modeling of combustion aerosol in Africa}

A. Konare et al.

Title Page

Fig. 8. Comparison between simulated and measured surface $\mathrm{BC}$ (in $\mu \mathrm{g} / \mathrm{m}^{3}$ ) at Skukuza during SAFARI 2000, for the period 30 August to 15 September 2000 (diamonds for observations, triangles for model results). Data have been extracted from Formenti et al., 2003).

14

4

Back

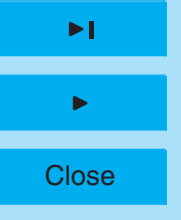

Full Screen / Esc

Printer-friendly Version 